\title{
Entropy-driven strand displacement reaction for ultrasensitive detection of circulating tumor DNA based on upconversion and $\mathrm{Fe}_{3} \mathrm{O}_{4}$ nanocrystals
}

\author{
Xiaorui Chen ${ }^{1}$, Ling Yang ${ }^{1,2}$, Shuang Liang ${ }^{1,2}$, Peipei Dang ${ }^{1,2}$, Dayong Jin $^{3}$, Ziyong Cheng ${ }^{1,2^{*}}$ and \\ Jun $\operatorname{Lin}^{1,2^{*}}$
}

\begin{abstract}
Early detection of cancer biomarkers applied in real-time disease diagnosis and therapies can increase the survival rate of patients. Circulating tumor DNA (ctDNA) as a typical cancer biomarker plays a great role in the process of tumor disease monitoring, especially in early diagnosis. Unfortunately, most ctDNA detection systems have not been widely used due to their low sensitivity, poor specificity, and high cost. Herein, we developed an alternative ctDNA detection system to present the levels of ctDNA by recording the fluorescence signals of the system containing upconversion nanoparticles (UCNPs), $\mathrm{Fe}_{3} \mathrm{O}_{4}$, and entropy-driven strand displacement reaction. The method has a practical sensitivity with a wide linear range from $100 \mathrm{amol} \mathrm{L}^{-1}$ to $1 \mathrm{nmol} \mathrm{L}^{-1}$ and a low detection limit of $1.6 \mathrm{amol} \mathrm{L} \mathrm{L}^{-1}$. Furthermore, the system demonstrates a practical application in mouse blood serum samples and meets the requirements for rapid, sensitive, specific, and economical diagnosis of cancers. Thus, this ctDNA detection system may have great potential for ctDNA detection and clinical diagnosis.
\end{abstract}

Keywords: upconversion nanoparticles, $\mathrm{Fe}_{3} \mathrm{O}_{4}$, entropy-driven strand displacement reaction, PIK3CA, ultrasensitive

\section{INTRODUCTION}

The secreted cancer biomarkers during the neoplastic process have been successfully used in early diagnosis of tumors due to their special response to the presence of tumor [1]. Recently, circulating tumor DNA (ctDNA) shows huge potential in cancer early diagnosis [2,3]. As a biomarker, the ctDNA detected in different tissues such as blood circulation, urine, and saliva can be released when tumor grows [4,5]. Therefore, the analysis of ctDNA provides enlightenment in tumor precision treatment and disease detection. In addition, it can detect tumor heterogeneity information through liquid biopsy and non-hematological testing due to its universality and flexibility [6]. The mutations and insertions of phosphatidylinositol-4,5-bisphosphate 3-kinase catalytic subunit alpha $(P I K 3 C A)$ gene have been verified in cancerous tissues such as lung, brain, and breast. PIK3CA is a nucleic acid with a length of $34 \mathrm{~kb}$, which encodes a protein consisting of 1068 amino acids located on chromosome 3q26.3. Somatic mutations in PIK3CA were demonstrated to increase its kinase activity, resulting in cellular transformation [7-9].

Considering the importance of ctDNA analysis, many conventional techniques, such as polymerase chain reaction (PCR), reverse transcription (RT)-PCR, and droplet digital PCR (ddPCR), have been established for ctDNA detection. However, the procedures of PCR are complicated to be precisely executed. Moreover, the measuring condition of enzyme and temperature of PCR are strict [10]. Thus, a sensitive but not complicated biosensor for ctDNA detection is in urgent need of development compared with the expensive, time-consuming, and lowsignal-to-noise-ratio traditional detection technique [1114]. Biosensors are devices that convert biological signals into electrical, optical, or thermodynamic signals. They can measure the biochemical signals of entire cells by physical devices such as fluorescent biosensors, optical transducers, surface-enhanced Raman scattering (SERS), localized surface plasmon resonance (LSPR), and

\footnotetext{
${ }^{1}$ State Key Laboratory of Rare Earth Resource Utilization, Changchun Institute of Applied Chemisry, Chinese Academy of Sciences, Changchun 130022, China

${ }^{2}$ University of Science and Technology of China, Hefei 230026, China

${ }^{3}$ Institute for Biomedical Materials and Devices Faculty of Science, University of Technology Sydney, 15 Broadway, Ultimo NSW 2007, Australia * Corresponding author (email: jlin@ciac.ac.cn)
} 
electrochemical biosensors [15-22]. Thus, the biosensors offer a more conducive approach to detect ctDNA because of their convenience and precision [23-29].

Herein, we developed an economical ultrasensitive detection system for PIK3CA, based on an entropy-driven strand displacement reaction (ESDR) mechanism, and using upconversion and $\mathrm{Fe}_{3} \mathrm{O}_{4}$ nanoparticles (NPs) as detective building blocks, which enhance the specific and ultrasensitive ctDNA detection of real samples. Different from the classical 1:1 ratio of target/probe molecular recognition event in biosensors, ESDR adopts a $1: N$ scale pattern, in which the probe is cleaved by the entropy reaction, binds to the target to release and reuse the target molecules, and thus realizes a target recycling amplification. ESDR helps to amplify the interaction between the free AuNPs and semiconducting polymer dots (Pdots), leading to significant improvement in analytical performance, and thus this method achieved a detection limit of $0.5 \mathrm{fmol} \mathrm{L}^{-1}$ [30-32]. The as-prepared upconversion NPs (UCNPs) are featured with visible fluorescence emission under near-infrared laser excitation, which enables the subsequent detections [33-37]. This method has several attractive features: enzyme-free, operable at room temperature, without any hairpin DNA, and ultrasensitive. Therefore, the current detection biosensor system for ctDNA has great potential for clinical monitoring.

\section{EXPERIMENTAL SECTION}

\section{Materials and reagents}

Sodium hydroxide $(\mathrm{NaOH})$, ammonium fluoride $\left(\mathrm{NH}_{4} \mathrm{~F}\right)$, cyclohexane, methanol and hydrochloric acid were purchased from Beijing Chemical Works (Beijing, China). Rare earth chlorides ( $\left.\mathrm{LnCl}_{3}, \mathrm{Ln}: \mathrm{Y}, \mathrm{Yb}, \mathrm{Er}\right)$ and iron(III) acetylacetonate $\left(\mathrm{Fe}(\mathrm{acac})_{3}\right)$ were purchased from Beijing HWRK Chem Co., Ltd. (Beijing, China). Bovine serum albumin (BSA), oleic acid (OA), oleylamine (OAm) and 1-octadecene (ODE) were purchased from Sigma-Aldrich (St. Louis, MO, USA). All of the nuclear acids, including Target, 30T, 30C, red-chain, orang-chain, blue-chain, purple-chain, Y1, Y2, Y3, pET-20b were synthesized and purified by Kumei Biology Co. (Changchun, China) and shown in Table S1. 4T1, Hela, BMSC, HFB cells were purchased from the Cell Bank of Chinese Academy of Sciences (Shanghai, China). These chemical reagents were all of analytical grade and used without any special purification.

\section{Material characterization}

The X-ray diffraction (XRD) patterns were tested with a
D8 Focus diffractometer (Bruker) by using $\mathrm{Cu} \mathrm{Ka}$ radiation $(\lambda=0.15405 \mathrm{~nm})$. Transmission electron microscopy (TEM) was recorded using an FEI Tecnai G2 STwin with a field emission gun operating at $200 \mathrm{kV}$. Fourier-transform infrared (FT-IR) spectra were carried out on a Vertex Perkin-Elmer 580BIR spectrophotometer (Bruker) with the $\mathrm{KBr}$ pellet technique. Upconversion fluorescence spectra were collected on a Hitachi F-7000 spectrophotometer excited with the $980-\mathrm{nm}$ continuouswave $(\mathrm{CW})$ laser. The X-ray photoelectron spectra (XPS) were taken on a VG ESCALAB MK II electron spectrometer using $\mathrm{Mg} \mathrm{Ka}(1200 \mathrm{eV})$ as the excitation source, with the samples put on silicon slices.

\section{Synthesis of OA-modified UCNPs}

The OA-modified UCNPs $\left(\mathrm{NaYF}_{4}: 20 \% \mathrm{Yb}, 2 \% \mathrm{Er}\right.$, described as UCNP-OA), were synthesized according to the previous reports $[38,39]$. The detailed processes are described below. $\mathrm{YCl}_{3}(0.78 \mathrm{mmol}), 0.20 \mathrm{mmol} \mathrm{YbCl}_{3}$, and $0.02 \mathrm{mmol} \mathrm{ErCl}_{3}$ aqueous solutions were added into a $100-\mathrm{mL}$ three-necked flask, and then the mixture was heated to $80^{\circ} \mathrm{C}$ under stirring until white precipitate separated out. Six milliliter of OA was added into the flask; the mixture was heated to $130^{\circ} \mathrm{C}$ to dissolve the white precipitate completely. Fifteen milliliter of ODE was added into the solution, then heated to $150^{\circ} \mathrm{C}$ and maintained for $30 \mathrm{~min}$. Next, $10 \mathrm{~mL}$ of methanol (containing $2.5 \mathrm{mmol} \mathrm{NaOH}, 4 \mathrm{mmol} \mathrm{NH}_{4} \mathrm{~F}$ ) was added into the flask when the mixture was cooled down to room temperature, which was then reheated to $70^{\circ} \mathrm{C}$ and maintained $30 \mathrm{~min}$ to remove the methanol. The mixture was degassed at $100^{\circ} \mathrm{C}$ for $20 \mathrm{~min}$, then heated to $300^{\circ} \mathrm{C}$, and kept at this temperature for $90 \mathrm{~min}$ under nitrogen protection. The mixture was cooled down to $30^{\circ} \mathrm{C}$ naturally, and then washed three times with $15 \mathrm{~mL}$ of ethanol and $5 \mathrm{~mL}$ of cyclohexane together. Finally, the UCNPs were dispersed in cyclohexane.

\section{Synthesis of OAm-modified $\mathrm{Fe}_{3} \mathrm{O}_{4} \mathrm{NPs}$}

The OAm-modified $\mathrm{Fe}_{3} \mathrm{O}_{4}$ NPs (described as $\mathrm{Fe}_{3} \mathrm{O}_{4}$ $\mathrm{OAm}$ ) were synthesized according to the previous reports [38]. $\mathrm{Fe}(\mathrm{acac})_{3}(1.06 \mathrm{~g})$ and $20 \mathrm{~mL}$ of OAm were added into a $100-\mathrm{mL}$ three-necked flask. Then the mixture was heated to $110^{\circ} \mathrm{C}$ for $30 \mathrm{~min}$ under the vacuum condition and next heated to $310^{\circ} \mathrm{C}$ and maintained at this temperature for $1 \mathrm{~h}$ under nitrogen protection. Then, the mixture was cooled down to room temperature naturally, and the $\mathrm{Fe}_{3} \mathrm{O}_{4}$-OAm NPs were collected by a magnet and washed with ethanol three times and then dispersed with tetrahydrofuran. 


\section{Synthesis of DNA-grafted UCNPs and $\mathrm{Fe}_{3} \mathrm{O}_{4} \mathrm{NPs}$}

UCNP-OA or $\mathrm{Fe}_{3} \mathrm{O}_{4}$-OAm $(40 \mathrm{mg})$ were dispersed in $2 \mathrm{~mL}$ of hydrochloric acid $\left(1.2 \mathrm{~mol} \mathrm{~L}^{-1}\right)$ under stirring at room temperature for $1 \mathrm{~h}$. The UCNPs or $\mathrm{Fe}_{3} \mathrm{O}_{4} \mathrm{NPs}$ were collected by centrifugation and washed with ultrapure water three times. Then UCNPs or $\mathrm{Fe}_{3} \mathrm{O}_{4}$ NPs were dispersed in $10 \mathrm{~mL}$ of ultrapure water with $1 \mathrm{mg} 30 \mathrm{~T}$ or $30 \mathrm{C}$ under stirring overnight. The UCNPs-DNA and $\mathrm{Fe}_{3} \mathrm{O}_{4}$-DNA were collected by centrifugation and washed with $20 \mathrm{~mL}$ of Tris- $\mathrm{HCl}\left(20 \mathrm{mmol} \mathrm{L}^{-1}, \mathrm{pH} 7.4\right)$ five times to remove free $30 \mathrm{~T}$ or $30 \mathrm{C}$. Finally, the UCNPs-DNA and $\mathrm{Fe}_{3} \mathrm{O}_{4}$-DNA were dispersed in $10 \mathrm{~mL}$ of ultrapure water and stored at $4^{\circ} \mathrm{C}$.

\section{Synthesis of UCNP-DNA- $\mathrm{Fe}_{3} \mathrm{O}_{4}$ nanosensors}

UCNP-DNA $(40 \mathrm{mg})$ was added into $10 \mathrm{~mL}$ DNA ( $0.033 \mathrm{mg}$ orange-chain or red-chain) hybridization buffer $\left(20 \mathrm{mmol} \mathrm{L} \mathrm{L}^{-1}\right.$ Tris- $\mathrm{HCl}, 100 \mathrm{mmol} \mathrm{L}^{-1} \mathrm{NaCl}$, $2 \mathrm{mmol} \mathrm{L}^{-1} \mathrm{KCl}, 1 \mathrm{mmol} \mathrm{L}^{-1} \mathrm{MgCl}_{2}, \mathrm{pH} 7.4$ ), and then stirred for $1 \mathrm{~h}$ at $37^{\circ} \mathrm{C}$. The same procedure was applied for $\mathrm{Fe}_{3} \mathrm{O}_{4}$-DNA with purple-chain. The UCNP-orange chain, UCNP-red-chain and $\mathrm{Fe}_{3} \mathrm{O}_{4}$-purple-chain were collected by centrifugation and washed with ultrapure water three times and stored at $4^{\circ} \mathrm{C}$. Next, $20 \mathrm{mg}$ UCNPorange-chain, UCNP-red-chain and $\mathrm{Fe}_{3} \mathrm{O}_{4}$-purple-chain were dispersed in $40 \mathrm{~mL}$ DNA hybridization buffer, maintained at $16^{\circ} \mathrm{C}$ for $12 \mathrm{~h}$, then collected by a magnet and stored at $4^{\circ} \mathrm{C}$.

\section{Mice and serum collection}

All experiments of mice were approved by the Institutional Animal Care and Use Committee of Jilin University. $\mathrm{BALB} / \mathrm{c}$ female mice (6 weeks old, weighing 18-20 g) were purchased from Changchun Institute of Biological Products, and then housed in the IVC animal facilities. About $5 \times 10^{6} 4 \mathrm{~T} 1$ cells in phosphate buffered saline (PBS, $0.1 \mathrm{~mL}$ ) were implanted subcutaneously in the area near the leg of each mouse. The blood $(0.1 \mathrm{~mL})$ of mice was collected from the eye edge by using a capillary every week. Then let the blood sit at $37^{\circ} \mathrm{C}$ for $1 \mathrm{~h}$ and $4^{\circ} \mathrm{C}$ for $12 \mathrm{~h}$, successively. The serum was collected by centrifugation, and $0.005 \mathrm{~mL}$ serum was taken, diluted with PBS to $5 \mathrm{~mL}$ and stored at $-20^{\circ} \mathrm{C}$.

\section{Detection of ctDNA}

One milliliter of UCNP-DNA- $\mathrm{Fe}_{3} \mathrm{O}_{4}\left(0.01 \mathrm{mg} \mathrm{mL} \mathrm{m}^{-1}\right)$, $0.01 \mathrm{~mL}$ of blue-chain $\left(10 \mathrm{nmol} \mathrm{L}^{-1}\right)$, and $1 \mathrm{~mL}$ sample $\left(100 \mathrm{amol} \mathrm{L}{ }^{-1}, 1 \mathrm{fmol} \mathrm{L}^{-1}, 10 \mathrm{fmol} \mathrm{L}{ }^{-1}, 100 \mathrm{fmol} \mathrm{L}^{-1}\right.$, 1 pmol L ${ }^{-1}, 10$ pmol L $\mathrm{L}^{-1}, 100 \mathrm{pmol} \mathrm{L}^{-1}, 1 \mathrm{nmol} \mathrm{L}^{-1}$ PIK3CA, 0.01 g BSA, 20 ng pET-20b, Y1, Y2, Y3, mouse serum, cell medium) were mixed into a $2-\mathrm{mL}$ reagent bottle, shaken at $37^{\circ} \mathrm{C}$ for $1 \mathrm{~h}$. The upconversion luminescence (UCL) spectra of the samples were measured under $980-\mathrm{nm}$ CW laser excitation after magnetic separation.

\section{RESULTS AND DISCUSSION}

We constructed an ultrasensitive optical method for the detection of PIK3CA. Fig. 1 shows the detailed sensing principle of this detection system. In the first step, the red-chain UCNP and orange-chain UCNP were designed to link with the purple-chain $\mathrm{Fe}_{3} \mathrm{O}_{4} \mathrm{NP}$ to form a nanosensor in accordance with the principle of base complementary pairing. In the presence of target sequence, it will bind to the purple chain, and promote the release of the orange-chain UCNP from nanosensors through competition. Next, the blue-chain will bind to the unbound position between the target sequence and the redchain. Based on the competition, the red-chain UCNP will be released first, followed by the release of the target sequence. In this way, the target sequence can continue to react with the new nanosensor, so that more UCNPs can be released from the reaction system in this cycle. At the end of the reaction, the DNA strand with $\mathrm{Fe}_{3} \mathrm{O}_{4}$ NPs will be adsorbed with a magnet. At this moment, all the NPs existing in the supernatant of the reaction system are the UCNPs with DNA strand. It can emit strong green fluorescence under 980-nm laser excitation. When there is a growth in the number of target sequence, the upconversion fluorescence will be enhanced along with the increase in the amount of UCNPs in the supernatant. The sensitivity for the detection system was greatly enhanced in this strategy due to the fact of circular target sequence and the upconversion fluorescence with low interference noise.

UCNPs and $\mathrm{Fe}_{3} \mathrm{O}_{4}$ NPs were synthesized according to a well-established method [38,39]. The XRD patterns (Figs S1, S2) confirmed the good crystal structure of $\mathrm{NaYF}_{4}$ and $\mathrm{Fe}_{3} \mathrm{O}_{4}$ NPs. TEM images indicated that the UCNPs and $\mathrm{Fe}_{3} \mathrm{O}_{4}$ NPs retained their original morphologies after DNA grafting without obvious aggregation (Fig. 2a-d). The UCL spectra of UCNP-OA and UCNPDNA are displayed in Fig. S3. Three main characteristic peaks at 521,540, and $655 \mathrm{~nm}$ can be attributed to the electronic transitions ${ }^{2} \mathrm{H}_{11 / 2} \rightarrow{ }^{4} \mathrm{I}_{15 / 2},{ }^{4} \mathrm{~S}_{3 / 2} \rightarrow{ }^{4} \mathrm{I}_{15 / 2}$, and ${ }^{4} \mathrm{~F}_{9 / 2} \rightarrow{ }^{4} \mathrm{I}_{15 / 2}$ of $\mathrm{Er}^{3+}$, respectively. The multiphotonic energy transfer mechanism of $\beta-\mathrm{NaYF}_{4}: \mathrm{Yb}, \mathrm{Er} \mathrm{NPs}$ was summarized in Fig. S4. Moreover, the DNA-modified UCNPs have the similar fluorescence intensity compared with UCNP-OA under the same 980-nm laser excitation, 
$\mathbf{a}$
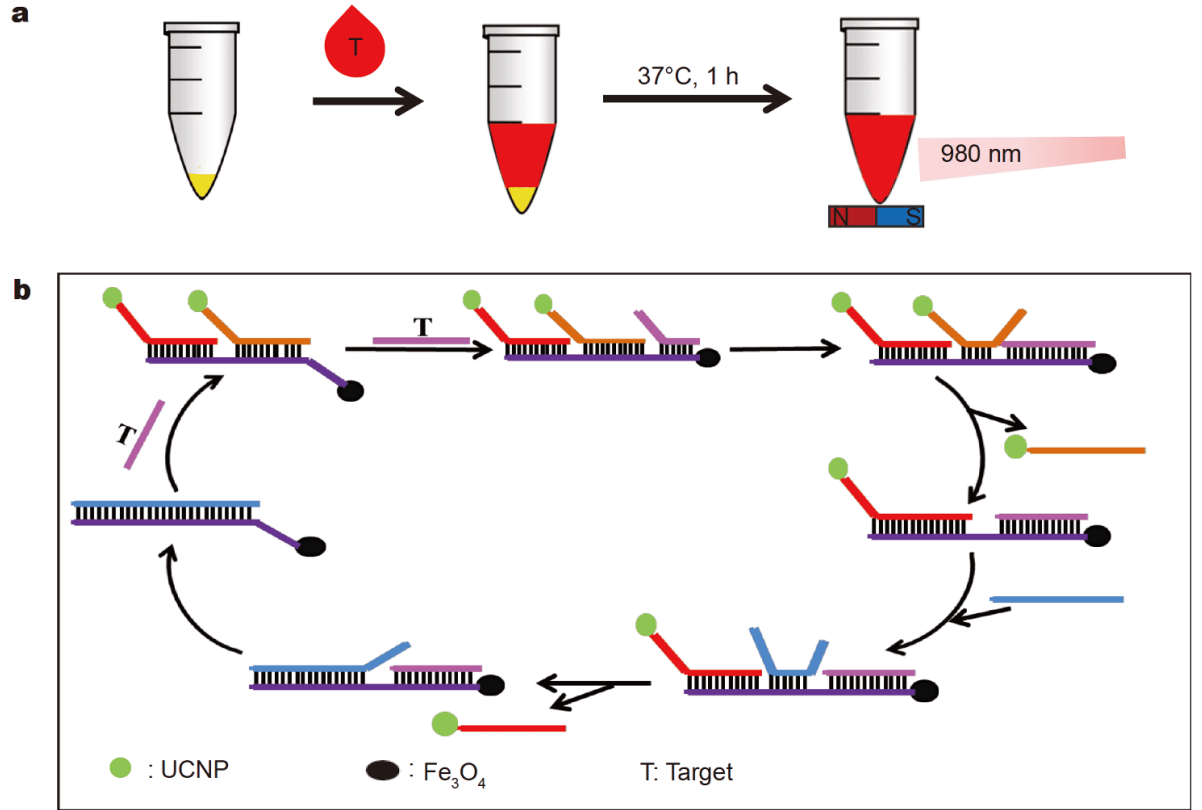

Figure 1 Schematic illustration of the optical detection system for PIK3CA. (a) The process of the PIK3CA detection; (b) the sensing principle.

indicating that grafting with DNA has no effect on UCNPs' fluorescence intensity. The $\mathrm{Fe}_{3} \mathrm{O}_{4}$-DNA retained intense magnetic and superparamagnetic characteristics (Figs S5 and S6). The XPS surveyed the elemental composition of the NPs. The results showed that $\mathrm{Na}, \mathrm{Y}, \mathrm{F}, \mathrm{Yb}$, $\mathrm{Er}, \mathrm{C}$, and $\mathrm{O}$ were major elements on the surface of UCNPs (Fig. S7), and $\mathrm{Fe}, \mathrm{O}$, and $\mathrm{C}$ are major elements on the surface of $\mathrm{Fe}_{3} \mathrm{O}_{4}$ NPs (Fig. S8). Furthermore, the P 2p signal was also detected through the high-resolution XPS (Fig. 2e, f). The results revealed that the DNA had linked to the surface of UCNPs and $\mathrm{Fe}_{3} \mathrm{O}_{4}$ NPs. Besides, FT-IR (Figs S9 and S10) indicated the obvious ligand change on the NP surface. Compared with UCNP-OA and $\mathrm{Fe}_{3} \mathrm{O}_{4}{ }^{-}$ $\mathrm{OAm}, \mathrm{UCNP}$-DNA and $\mathrm{Fe}_{3} \mathrm{O}_{4}$-DNA revealed asymmetric and symmetric vibrations of phosphate at 1228 and $1087 \mathrm{~cm}^{-1}$ in the spectra, respectively. These results overall demonstrate the successful grafting of DNA onto the UCNPs and $\mathrm{Fe}_{3} \mathrm{O}_{4} \mathrm{NPs}$.

UCNPs and magnetic $\mathrm{Fe}_{3} \mathrm{O}_{4}$ NPs were linked together through the DNA strand grafted on the surface of NPs (Fig. 3a, Fig. S11). To investigate the detection limit, we detected the response of nanosensors with different amounts of PIK3CA. With the increase of target DNA concentration, the intensity of upconversion emission in the supernatant after magnetic separation increased (Fig. 3b). Fig. 3c shows the positive linear dependence of the luminescent intensity $\left(\Delta I=I_{\text {Target }}-I_{\mathrm{PBS}}\right)$ on the concentration of the target DNA. The regression equation is $y=27.577 x+573.55, R^{2}=0.9671, n=8$, in which $y$ and $x$ stand for the intensity of fluorescence (a.u.) and logarithmic target sequence concentration, respectively. The PIK3CA concentration correlates well linearly with the UCL intensity at $550 \mathrm{~nm}$ from $1 \mathrm{nmol} \mathrm{L}^{-1}$ to $100 \mathrm{amol} \mathrm{L}^{-1}$. The limit of detection down to $1.6 \mathrm{amol} \mathrm{L}^{-1}$ shows sufficient sensitivity in PIK3CA detection. The enhanced sensitivity might origin from two aspects. On one hand, the strong upconversion fluorescence employs 980-nm laser excitation and eliminates the background fluorescence. On the other hand, ESDR makes target sequence recycling used and amplifies the signal.

To evaluate the discrimination ability under complex conditions and single-base-mismatch, the nanosensors were mixed with $1 \mathrm{~mL}$ target sequence $\left(1 \mathrm{pmol} \mathrm{L}^{-1}\right)$, BSA (protein, $0.01 \mathrm{~g}$ ), pET-20b (plasmid, $20 \mathrm{ng}$ ), mixture of BSA (0.01 g) and pET-20b (20 ng), Y1, Y2, Y3 (Y1, Y2, Y3 all have one base mismatched, $1 \mathrm{pmol} \mathrm{L}^{-1}$ ) and PBS, respectively. After magnetic separation, the results were determined by the fluorescence intensity of the UCNPs. As shown in Fig. 4a, the BSA, pET-20b, mixture of BSA and pET-20b all exhibited fluorescence intensities comparable to that in PBS, and lower than that of the target sequence. Excellent specificity toward the target sequence is thus defined. As shown in Fig. 4b, Y1, Y2, Y3 do not give rise to fluorescence intensity response in comparison with PBS. The results clearly illustrate that UCNP-DNA- 
a

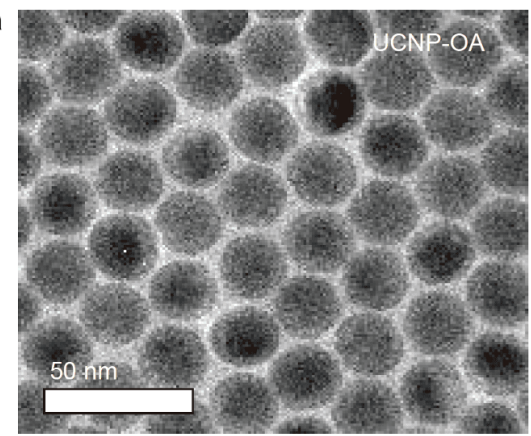

C
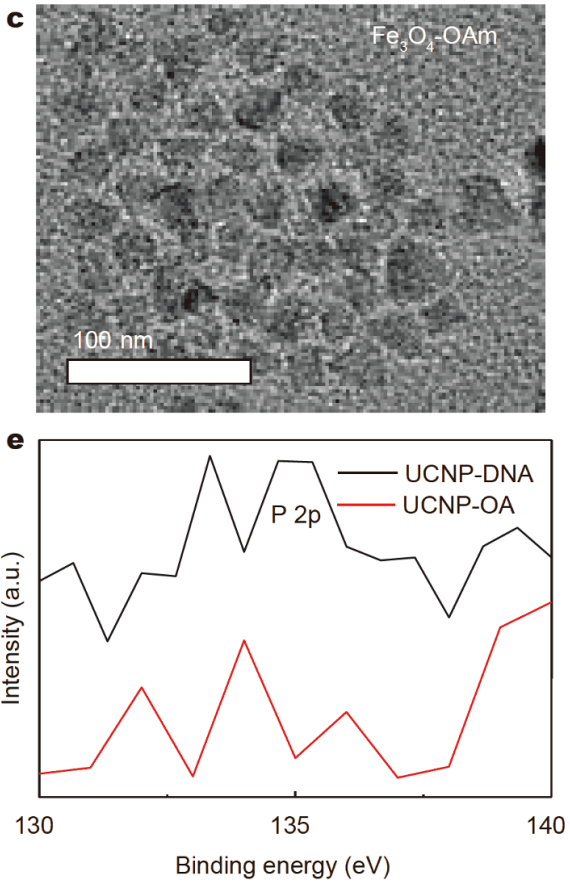

b
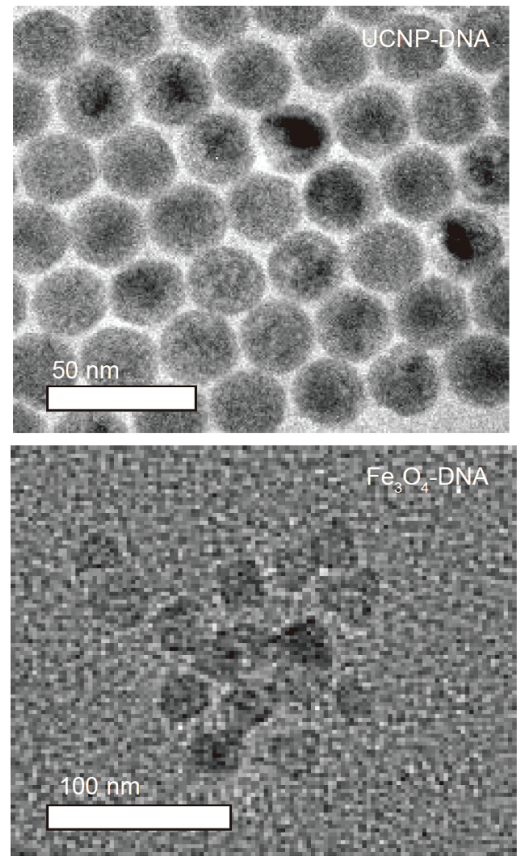

$\mathbf{f}$

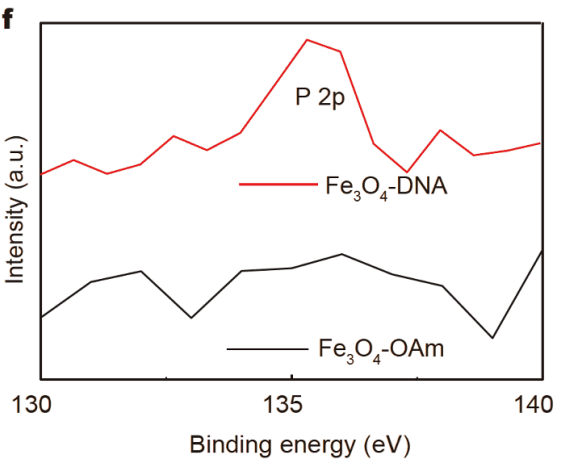

Figure 2 TEM images of the $\mathrm{NaYF}_{4}: \mathrm{Yb}$,Er with $\mathrm{OA}$ modification (a) and after grafting with DNA (b). TEM images of the Fe $\mathrm{O}_{4}$ with $\mathrm{OAm}$ modification (c) and after grafting with DNA (d). (e) XPS of UCNP-OA and UCNP-DNA: high-resolution P $2 p$ peak from 125 to 140 eV. (f) XPS of $\mathrm{Fe}_{3} \mathrm{O}_{4}$-OAm and $\mathrm{Fe}_{3} \mathrm{O}_{4}$-DNA: high-resolution $\mathrm{P} 2 \mathrm{p}$ peak from 125 to $140 \mathrm{eV}$.

$\mathrm{Fe}_{3} \mathrm{O}_{4}$ nanosensors can be highly selective to detect singlebase-mismatch. These results reveal this detection system has potential in the real sample analysis, based on the high selectivity.

To demonstrate the potential application of the UCNPDNA- $\mathrm{Fe}_{3} \mathrm{O}_{4}$ nanosensors, we further investigated the detection of the expression level of PIK3CA in four different cell lines (4T1, Hela, BMSC, HFB) and a 4T1 tumor mouse model. The cells were all cultured for $48 \mathrm{~h}$, and centrifuged to collect the media, which were then mixed with the nanosensors to detect the fluorescence intensity. As shown in Fig. 5a, the nanosensor measurements reveal that the level of PIK3CA in 4T1 cells is significantly higher than that in Hela, BMSC and HFB, under the condition of the same amounts of cells. Furthermore, in
Fig. 5b, with increasing amount of the Hela cells, the fluorescence intensity is more and more strong, which indicates that these nanosensors are sensitive to detect the amounts of PIK3CA in cell cultures.

We established a 4T1 tumor mouse model to demonstrate the relationship of the detected level of ctDNA in serum with tumor volume, which clinically responses to therapies. The treatment and no-treatment groups were implanted under skin subcutaneously in the area near the leg with $5 \times 10^{6} 4 \mathrm{~T} 1$ cells in PBS $(0.1 \mathrm{~mL})$, and surgery was carried out for the treatment group after 14 days. From Fig. 5c, it can be seen that the PIK3CA levels in serum were obviously higher than that in the PBS control group, and the difference was greatly increased with the tumor growing. In contrast, from Fig. 5d, after treatment 

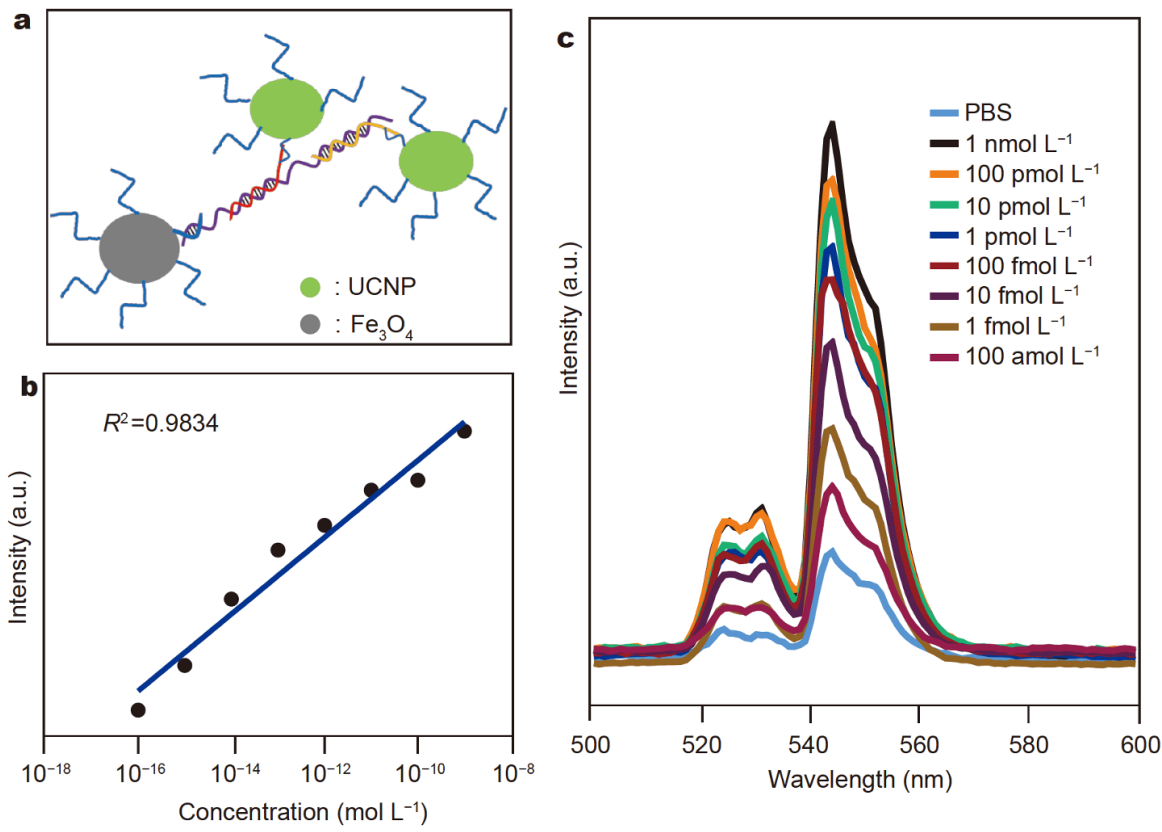

Figure 3 (a) Principle of nanosensor assembly. (b) The UCL spectra of the UCNPs under the 980-nm laser excitation. The nanosensor mixtures with different concentrations of PIK3CA, from $100 \mathrm{amol} \mathrm{L}{ }^{-1}$ to $1 \mathrm{nmol} \mathrm{L}^{-1}$, were maintained at $37^{\circ} \mathrm{C}$ for $1 \mathrm{~h}$. The UCL spectra of UCNPs were detected after magnetic separation. (c) The linear range of fluorescence intensity of the UCL spectra versus PIK3CA concentration at $550 \mathrm{~nm}(n=8)$. The 980-nm laser power is $1 \mathrm{~W} \mathrm{~cm}^{-2}$.
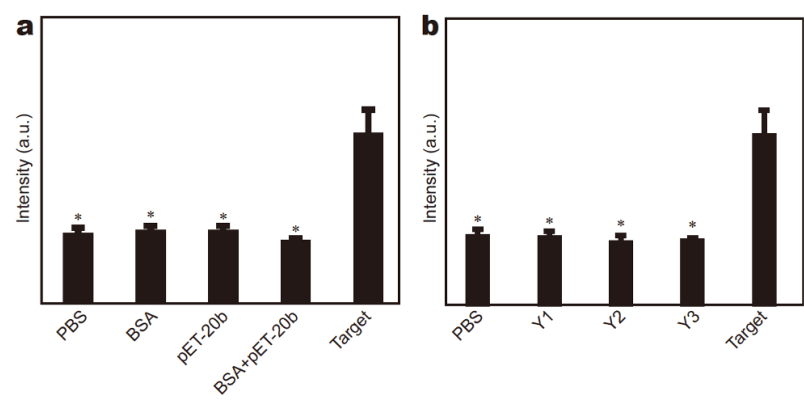

Figure 4 (a) Selectivity investigation of nanosensors for PBS, BSA $(0.01 \mathrm{~g})$, pET-20b (20 ng), mixture of BSA (0.01 g) and pET-20b (20 ng), and Target $\left(1 \mathrm{pmol} \mathrm{L}^{-1}\right)$. (b) Responses of the nanosensors toward the single-base-mismatched sequence (each at a concentration of $1 \mathrm{pmol} \mathrm{L}^{-1}$ in PBS), PBS, and Target $\left(1 \mathrm{pmol} \mathrm{L}^{-1}\right)$. Statistical difference compared with PBS group by one-way ANOVA, $t$-test, ${ }^{*} P<0.05$.

of removing tumor by surgery on the 14th day, the level of PIK3CA began to decrease rapidly. Therefore, during tumor volume change, the levels of PIK3CA in mouse serum have been detected through this system. It is demonstrated that this detection system has great potential in tumor burden monitoring and evaluation of the therapy.

\section{CONCLUSIONS}

In summary, we have established an ultrasensitive en-
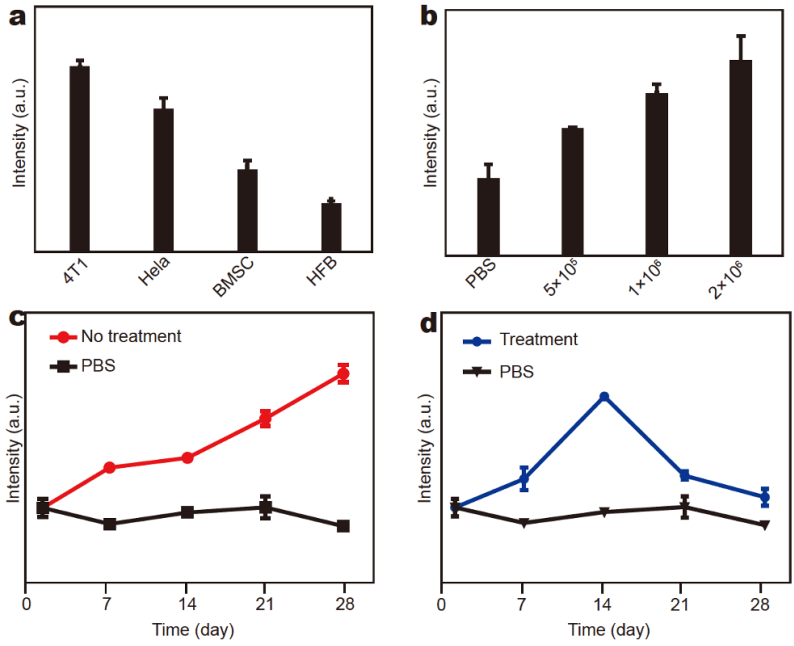

Figure 5 (a) Detection of the expression levels of PIK3CA in different cell lines (4T1, Hela, BMSC, HFB). (b) Detection of the expression levels of PIK3CA in different amounts of Hela cells $\left(5 \times 10^{5}, 1 \times 10^{6}, 2 \times 10^{6}\right)$. (c) Tumor burden monitoring. (d) The effect of surgery treatment.

zyme-free optical nanosensor based on UCNPs and $\mathrm{Fe}_{3} \mathrm{O}_{4}$ NPs for detection of ctDNA. The UCNPs and $\mathrm{Fe}_{3} \mathrm{O}_{4} \mathrm{NPs}$ were synthesized and grafted with DNA successfully. The system performed ultrahigh sensitivity due to ESDR by recycling the target sequences, releasing the chain with UCNP, and reading out by strong green fluorescence of 
UCNPs under 980-nm laser excitation. This method can also be performed at room temperature without any enzyme or hairpin DNA. In serum samples, the ctDNA was successfully detected through this optical nanosensor with an ultra-high sensitivity down to $1.6 \mathrm{amol} \mathrm{L} \mathrm{L}^{-1}$. This strategy provided an easy-to-handle, rapid, supersensitive, and low-cost detection system, showing huge potential in clinical application, including noninvasive early diagnosis and monitoring disease progression.

\section{Received 23 December 2020; accepted 18 February 2021;} published online 27 May 2021

1 Cohen JD, Javed AA, Thoburn C, et al. Combined circulating tumor DNA and protein biomarker-based liquid biopsy for the earlier detection of pancreatic cancers. Proc Natl Acad Sci USA, 2017, 114: 10202-10207

2 Wan JCM, Massie C, Garcia-Corbacho J, et al. Liquid biopsies come of age: Towards implementation of circulating tumour DNA. Nat Rev Cancer, 2017, 17: 223-238

3 Agashe R, Kurzrock R. Circulating tumor cells: from the laboratory to the cancer clinic. Cancers, 2020, 12: 2361

4 Chabon JJ, Simmons AD, Lovejoy AF, et al. Circulating tumour DNA profiling reveals heterogeneity of EGFR inhibitor resistance mechanisms in lung cancer patients. Nat Commun, 2016, 7: 11815

5 Moss EL, Gorsia DN, Collins A, et al. Utility of circulating tumor DNA for detection and monitoring of endometrial cancer recurrence and progression. Cancers, 2020, 12: 2231

6 André F, Ciruelos E, Rubovszky G, et al. Alpelisib for PIK3CAmutated, hormone receptor-positive advanced breast cancer. $\mathrm{N}$ Engl J Med, 2019, 380: 1929-1940

7 Juric D, Janku F, Rodón J, et al. Alpelisib plus fulvestrant in PIK3CA-altered and PIK3CA-wild-type estrogen receptor-positive advanced breast cancer. JAMA Oncol, 2019, 5: e184475

8 Noorolyai S, Shajari N, Baghbani E, et al. The relation between PI3K/AKT signalling pathway and cancer. Gene, 2019, 698: 120128

9 Ebrahimi SB, Samanta D, Mirkin CA. DNA-based nanostructures for live-cell analysis. J Am Chem Soc, 2020, 142: 11343-11356

10 Heitzer E, Ulz P, Geigl JB. Circulating tumor DNA as a liquid biopsy for cancer. Clin Chem, 2015, 61: 112-123

11 Olsson E, Winter C, George A, et al. Serial monitoring of circulating tumor DNA in patients with primary breast cancer for detection of occult metastatic disease. EMBO Mol Med, 2015, 7: 1034-1047

12 Siravegna G, Marsoni S, Siena S, et al. Integrating liquid biopsies into the management of cancer. Nat Rev Clin Oncol, 2017, 14: 531-548

13 Thress KS, Brant R, Carr TH, et al. EGFR mutation detection in ctDNA from NSCLC patient plasma: A cross-platform comparison of leading technologies to support the clinical development of AZD9291. Lung Cancer, 2015, 90: 509-515

14 Bo B, Zhang T, Jiang Y, et al. Triple signal amplification strategy for ultrasensitive determination of miRNA based on duplex specific nuclease and bridge DNA-gold nanoparticles. Anal Chem, 2018, 90: 2395-2400

15 Chai H, Cheng W, Xu L, et al. Fabrication of polymeric ferrocene nanoparticles for electrochemical aptasensing of protein with tar- get-catalyzed hairpin assembly. Anal Chem, 2019, 91: 9940-9945

16 Chai H, Miao P. Bipedal DNA walker based electrochemical genosensing strategy. Anal Chem, 2019, 91: 4953-4957

17 Chen X, Tang Y, Yan R, et al. Ultrasensitive detection of ctDNA by target-mediated in situ growth of DNA three-way junction on the electrode. ChemElectroChem, 2019, 7: 64-68

18 Dong Q, Liu Q, Guo L, et al. A signal-flexible gene diagnostic strategy coupling loop-mediated isothermal amplification with hybridization chain reaction. Anal Chim Acta, 2019, 1079: 171-179

19 Liu L, Zhang H, Wang Z, et al. Peptide-functionalized upconversion nanoparticles-based FRET sensing platform for Caspase-9 activity detection in vitro and in vivo. Biosens Bioelectron, 2019, 141: 111403

20 Tadimety A, Zhang Y, Kready KM, et al. Design of peptide nucleic acid probes on plasmonic gold nanorods for detection of circulating tumor DNA point mutations. Biosens Bioelectron, 2019, 130: $236-244$

21 Thomas RK, Sukumaran S, Sudarsanakumar C. An insight into the comparative binding affinities of chlorogenic acid functionalized gold and silver nanoparticles with ctDNA along with its cytotoxicity analysis. J Mol Liquids, 2019, 287: 110911

$22 \mathrm{Gu} \mathrm{T}, \mathrm{Li} \mathrm{Z}$, Ren Z, et al. Rare-earth-doped upconversion nanocrystals embedded mesoporous silica nanoparticles for multiple microRNA detection. Chem Eng J, 2019, 374: 863-869

$23 \mathrm{Hu} \mathrm{P}$, Zhang S, Wu T, et al. Fe-Au nanoparticle-coupling for ultrasensitive detections of circulating tumor DNA. Adv Mater, 2018, 30: 1801690

24 Jiang Y, Tang Y, Miao P. Polydopamine nanosphere@silver nanoclusters for fluorescence detection of multiplex tumor markers. Nanoscale, 2019, 11: 8119-8123

25 Jo EJ, Byun JY, Mun H, et al. Single-step LRET aptasensor for rapid mycotoxin detection. Anal Chem, 2018, 90: 716-722

26 Li B, Liu Y, Liu Y, et al. Construction of dual-color probes with target-triggered signal amplification for in situ single-molecule imaging of microRNA. ACS Nano, 2020, 14: 8116-8125

27 Mao X, Pan S, Zhou D, et al. Fabrication of DNAzyme-functionalized hydrogel and its application for visible detection of circulating tumor DNA. Sens Actuat B-Chem, 2019, 285: 385-390

28 Savli H, Sertdemir N, Aydin D, et al. TP53, EGFR and PIK3CA gene variations observed as prominent biomarkers in breast and lung cancer by plasma cell-free DNA genomic testing. J Biotech, 2019, 300: 87-93

29 Sun Y, Zhao C, Yan Z, et al. Simple and sensitive microbial pathogen detection using a label-free DNA amplification assay. Chem Commun, 2016, 52: 7505-7508

30 Uhd J, Miotke L, Ji HP, et al. Ultra-fast detection and quantification of nucleic acids by amplification-free fluorescence assay. Analyst, 2020, 145: 5836-5844

31 Ali M, Sajid M, Khalid MAU, et al. A fluorescent lateral flow biosensor for the quantitative detection of Vaspin using upconverting nanoparticles. Spectrochim Acta Part A-Mol Biomol Spectr, 2020, 226: 117610

32 Zhang N, Shi XM, Guo HQ, et al. Gold nanoparticle couples with entropy-driven toehold-mediated DNA strand displacement reaction on magnetic beads: Toward ultrasensitive energy-transferbased photoelectrochemical detection of miRNA-141 in real blood sample. Anal Chem, 2018, 90: 11892-11898

33 Gao R, Hao C, Xu L, et al. Spiny nanorod and upconversion nanoparticle satellite assemblies for ultrasensitive detection of messenger RNA in living cells. Anal Chem, 2018, 90: 5414-5421 
34 Ghosh S, Chang YF, Yang DM, et al. Upconversion nanoparticlemOrange protein FRET nanoprobes for self-ratiometric/ratiometric determination of intracellular $\mathrm{pH}$, and single cell $\mathrm{pH}$ imaging. Biosens Bioelectron, 2020, 155: 112115

35 Li H, Wang X, Ohulchanskyy TY, et al. Lanthanide-doped nearinfrared nanoparticles for biophotonics. Adv Mater, 2021, 33: 2000678

36 Law GL, Wong KL, Lau KK, et al. Nonlinear optical activity in dipolar organic-lanthanide complexes. J Mater Chem, 2010, 20: 4074-4079

37 Law GL, Wong KL, Zhou X, et al. Crystal structure and luminescence of lanthanide monodentate complexes $\left[\operatorname{Ln}\left(\mathrm{C}_{4} \mathrm{~N}_{4} \mathrm{H}_{6} \mathrm{O}\right)_{2}\right.$ $\left.\left(\mathrm{H}_{2} \mathrm{O}\right)_{6}\right] \mathrm{Cl}_{3}$ and $\left[\mathrm{Ln}\left(\mathrm{C}_{4} \mathrm{~N}_{4} \mathrm{H}_{6} \mathrm{O}\right)_{2}\left(\mathrm{H}_{2} \mathrm{O}\right)_{3}\left(\mathrm{NO}_{3}\right)_{3}\right](\mathrm{Ln}=\mathrm{Tb}$ or $\mathrm{Eu})$. Inorg Chem, 2005, 44: 4142-4144

38 Liu B, Deng X, Xie Z, et al. Thiol-ene click reaction as a facile and general approach for surface functionalization of colloidal nanocrystals. Adv Mater, 2017, 29: 1604878

39 Zhang R, Liang L, Meng Q, et al. Responsive upconversion nanoprobe for background-free hypochlorous acid detection and bioimaging. Small, 2018, 15: 1803712

Acknowledgements This work was supported by the Science and Technology Cooperation Project between Chinese and Australian Governments (2017YFE0132300), the National Natural Science Foundation of China (NSFC 51929201, 51672268, 51720105015, 51972138, 51872263, and 51828202), the Science and Technology Development Planning Project of Jilin Province (20190201232JC), and the CASCroucher Funding Scheme for Joint Laboratories (CAS18204).

Author contributions Chen X performed the experiments and wrote the draft of this manuscript. Yang L, liang S and Dang P helped design the cell and animal experiments. Cheng $\mathrm{Z}$ and Jin $\mathrm{D}$ provided suggestions and comments on the manuscript. Lin J proposed the project and revised the manuscript.

Conflict of interest The authors declare that they have no conflict of interest.

Supplementary information Experimental details and supporting data are available in the online version of the paper.

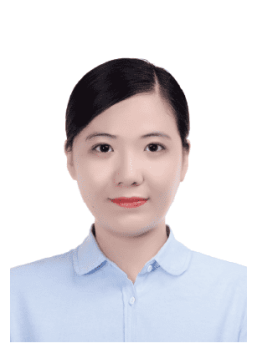

Xiaorui Chen received her BSc degree in biochemistry from the Northeast Agricultural University in 2016, and MSc degree in biochemistry from Jilin University in 2019. Currently, she worked at Changchun Institute of Applied Chemistry (CIAC), Chinese Academy of Sciences (CAS). Her research interests include nucleic acid detection technology and rare-earth-doped luminescent materials.

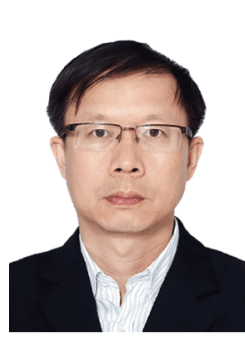

Ziyong Cheng earned his BSc degree in materials engineering from Changchun University of Technology in 1994 and $\mathrm{PhD}$ degree from the CIAC, CAS, in 2006. Following postdoctoral studies at the Max-Planck Institute for Polymer Research (Mainz, Germany), he returned to CIAC (2008) to take up an associate professor position in inorganic chemistry. His research interests are nanostructured materials including perovskite quantum dots in photoelectric applifor biomaterial-related fields. cations and polymer-inorganic nanocomposites

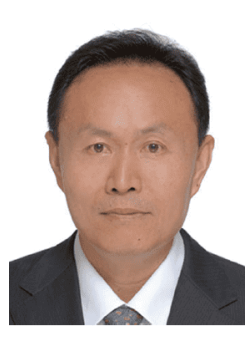

Jun Lin received his BSc and MSc degrees in inorganic chemistry from Jilin University in 1989 and 1992, respectively, and a $\mathrm{PhD}$ degree (inorganic chemistry) from CIAC, CAS, in 1995. He worked as a postdoctoral researcher for more than 4 years in the City University of Hong Kong (1996), Institute of New Materials (Germany, 1997), Virginia Commonwealth University (USA, 1998), and University of New Orleans (USA, 1999). He is a professor at the CIAC, CAS. His research interests include luminescent materials and multifunctional composite materials toward their applications in display, lighting and biomedical fields.

\section{一种以上转换和 $\mathrm{Fe}_{3} \mathrm{O}_{4}$ 纳米粒子为基础的超灵敏 ctDNA检测系统}

陈晓瑞 ${ }^{1}$ 杨玲 ${ }^{1,2}$, 梁双 ${ }^{1,2}$, 党佩佩 ${ }^{1,2}$, 金大勇 $^{3}$, 程子泳 ${ }^{1,2^{*}}$, 林君 ${ }^{1,2^{*}}$

摘要 $c t D N A$ 是重要的肿瘤标志物之一, 在肿瘤疾病的早期诊断和 临床监控方面发挥着重要作用. 目前, 常用的ctDNA检测方法通常 都缺乏足够的灵敏性和特异性, 不能满足实际诊疗的需要. 因此, 我 们急需一种新型的、超灵敏的ctDNA检测方法. 上转换纳米粒子是 一种优异的发光材料, 因其独特的发光特性在生物医学方面具有 重要应用. 因此, 我们设计了一种以上转换和 $\mathrm{Fe}_{3} \mathrm{O}_{4}$ 纳米粒子为基 础的ctDNA检测方法. 在该检测系统中, 上转换和 $\mathrm{Fe}_{3} \mathrm{O}_{4}$ 纳米粒子 通过DNA碱基互补配对原则自组装在一起. 目标序列可以通过熵 驱动链置换(ESDR) 反应将连着上转换纳米粒子的核酸链释放出来. 经磁性分离后, 上清液中上转换纳米粒子在 $980 \mathrm{~nm}$ 激光器激发下 的荧光强度与目标序列的浓度在 $1 \mathrm{nmol} \mathrm{L}-100 \mathrm{amol} \mathrm{L}{ }^{-1}$ 的范围内 具有非常好的线性关系, 经计算, 最低检出浓度为 $1.6 \mathrm{amol} \mathrm{L}^{-1}$. 此 外, 该检测系统在识别单碱基突变、实际细胞和血清样本的检测 中均有较好的应用. 因此, 该检测系统因为其灵敏性和特异性在肿 瘤早期诊断、疾病进行过程监控、治疗方法评价和愈后风险评估 等方面具有重大应用潜力. 